DOI: 10.24014 jush.v25i1.2176

\title{
A PHILOLOGICAL REPORT OF THE THEOLOGUS AUTODIDACTUS OF IBN AL-NAFIS BY MAX MEYERHOF AND JOSEPH SCHACHT
}

\author{
Maulana, ${ }^{1}$ Khotimah, ${ }^{2}$ dan Imron Rosidi ${ }^{2}$ \\ ${ }^{1}$ Universitas Islam Negeri Syarif Hidayatullah Jakarta, Indonesia \\ ${ }^{2}$ Universitas Islam Negeri Sultan Syarif Kasim Riau, Indonesia \\ maulana@uinjkt.ac.id
}

\begin{abstract}
Ibn al-Nafis is a monumental figure in Islamic scholarship. He wrote a fictional novel entitled "Al-Risalah al-Kamiliyah fi'l Sira al-Nabawiyah" which is translated as "Theologus autodidactus". This article does not focus on the content of this book but on the philological persepctive of how this book is edited by Joseph Schacht and Max Meyerhoff. Therefore, the question is whether this book which is edited by these two scholars is based on academic standards or not. Another question is how the editors study this text, particularly their main basis of editing this text.
\end{abstract}

Keywords: Ibn al-Nafis, manuscript, and Perfect Man.

\begin{abstract}
Abstrak
Ibn al-Nafis merupakan salah satu tokoh Islam yang monumental dalam tradisi kesarjanaan Islam. Dia mengarang sebuah novel fiksi yang terkenal Al-Risala Al-Kamiliya fi'l Sira alNabawiyya yang oleh sarjana Barat di sebut "theologus autodidactus". Dalam tulisan ini, tidak difokuskan pada detail isi buku tersebut, tetapi lebih pada kajian filologi tentang bagaimana teks karangan Ibn al-Nafis tersebut diedit oleh Joseph Schacht dan Max Meyerhoff. Karena itu, pertanyaan yang diajukan adalah apakah teks karya Ibn al-Nafis yang diedit oleh dua sarjana Barat tersebut sudah sesuai dengan kaidah-kaidah ilmiah atau tidak. Pertanyaan lainnya yang akan dicari dalam tulisan ini adalah bagaimana editor mengkaji teks Ibn al-Nafis tersebut, khususnya basis utama mereka dalam mengedit teks tersebut.
\end{abstract}

Keywords: Ibn al-Nafis, manuskrip, and Manusia Sempurna.

\section{Introduction}

This paper deals with a text edition of the Theologus Autodidactus of Ibn al-Nafis written by Joseph Schacht and Max Meyerhof. It aims to know whether this text edition is academic text edition or not based on philological study.

To answer this question, it is very important to understand its collations and editorial principles. It is because one will knows how the text edition was edited. As a result, one will understand its weaknesses and strengths. Also, it is important to know how the editors deal with the manuscripts, especially their main basis of the text edition.

Ibn al-Nafis' life and works are presented so that one can know other works produced by him. Another reason of providing Ibn al-Nafis' life and works in this article is to construct his biography based on other sources, not based on the text 
edition. Next, the text edition of Theologus Autodidactus and its manuscripts are described. After that, the collation and editorial principles are explained. And finally, a conclusion in the end of this paper is provided.

\section{Ibn al-Nafis' Life and Works}

\section{A. Ibn Nafis' Life}

Ibn al-Nafis is short name of 'Ala' alDin Abu '1-'Ala' 'Ali b. Abi 'L - Haram Al-Kurashi al-Dimaskhi. ${ }^{1} \mathrm{He}$ was born in 1213 A.D/607 A.H. in or near Damascus. ${ }^{2}$ According to Encyclopaedia of Islam, except for the date of his death only few facts of his life have been recorded. ${ }^{3}$ Hussain F. Nagamia wrote that "Ibn al-Nafis is described by Safadi as a tall, thin, smooth cheeked and chivalrous man." ${ }^{4}$

Ibn al-Nafis studied medicine at one medical college hospital in Damascus under Muhadhdhib al-Din 'Abd al-Rahim b. 'Ali known as al-Dakhwar (d. 628/ 120) . His medical college was called Nuri Hospital. This famous hospital was built by the Turkish Sultan Nur al-Din Mahmud ibn Zengi or known as Noor al-Diin al-Zanki in Damascus, after its conquest in $1154 .{ }^{6} \mathrm{He}$ did not only study medicine, he also learned grammar, logic and Islamic religious science.

After acquiring his expertise in medicine

\footnotetext{
${ }^{1}$ Max Meyerhof and Joseph Schacht, "Ibn al-Nafis", in Encyclopaedia of Islam, Jilid III, 897.

${ }^{2}$ Max Meyerhof is not sure about the exact place of Ibn al-nafis' birth. He says " ...presumably in the village of al-Kurashiyya..." See, Ibid.

${ }^{3}$ Ibid., 897. It was stated that “... because Ibn Abi Usaybi'a, although his contemporary, does not mention Ibn al-Nafis in his history of physicians; but al-'Umari and al-Safadi give detailed though anecdotal accounts of him and his personal habits..."

4Husain F. Nagamia MD, "Ibn al-Nafis: A Biographical Sketch of the Discover of Pulmonary and Coronary Circulation", in Journal of International Society of Islamic Medicine 1, no. 3 (2003), 22.

${ }^{5}$ Encyclopaedia of Islam, 897.

${ }^{6}$ Husain F. Nagamia, 23.

${ }^{7}$ Encyclopaedia of Islam, 897.
}

and jurisprudence, he moved to Egypt ${ }^{8}$ and worked in al-Nasiri Hospital then in alMansouri hospital where he became Chief of Physicians and the sultan's personal physician, namely Sultan Baybars I. ${ }^{9}$ Therefore, he became attached to the well-known alMansouri medical and hospital. Here he became actively involved in teaching, in writing and in medical practice. Consequently, Ibn al-Nafis was to become more famous than his teacher al-Dakhwar. ${ }^{10}$

He taught a number of students. One of them is Ibn al-Kuff. Also, he wrote a book about surgery. Besides that he also taught on Shafii law at the Masruriyya madrasa. Abu Hayyan al-Gharnati, a famous grammarian, is one of his students who praised his teaching. While Ibn al-Nahhas, the philologist, praised his style in Grammar. ${ }^{11}$

He became rich and had a luxurious house built for himself in Cairo. Before he died on 21 Dhu'l-Ka'da 687 / 18 december 1288 at the age of about 80 (lunar) years, he donated his house, library, and clinic to the al-Mansouri hospital. This hospital was founded by sultan Kalawun and only recently completed $(683 / 1284) .{ }^{12}$ His life was entirely devoted to medical practice. Therefore, he never married and remained a bachelor until his death. ${ }^{13}$

\section{B. Ibn al-Nafis' Works}

The literary activity of Ibn al-Nafis was important and extensive. Some of his works dealt with commentatory on medical works of the Greek and Islamic periods. ${ }^{14}$ He wrote in his works, as far as they are not commentatories, very few of references he

\footnotetext{
${ }^{8} \mathrm{Ibid}$. , it is not stated the exact year. It is only stated that "At unknown date he moved to Cairo..." see, Ibid.

${ }^{9}$ Ibid.

${ }^{10}$ Husain F. Nagamia, 23.

${ }^{11}$ Encyclopaedia of Islam, 897.

${ }^{12}$ Ibid.

${ }^{13}$ Husain F. Nagamia, 27 .

${ }^{14}$ Ibid.
} 
used. It is common in Islamic scholarship at that time that memory is an important technique on the methodology of learning. ${ }^{15}$

Husain F. Nagamia divided Ibn al-Nafis' works into five categories. ${ }^{16}$ However, here I summarize into four categories. It is because the last category has already included in other categories. The last catogory of Ibn al-Nafis' works is description of the pulmonary or lesser circulation. One of his works describing the pulmonary or lesser circulation is Sharh Tashrih al Qanun and this work has already included in the second category. Therefore, I do not mention the fifth category in this paper since it is only recurrence.

1. His commentaries on ancient Greek texts:

a. Sharh Fusul al-Buqrat: Commentary on Hippocratic Aphorism.

b. Sharh Taqdimat al-Ma'rifa: Commentary on Hippocratic Prognostic.

c. Ibidimiyya li Buqrat Watafsiruhu l'Amrad al-Wafideh: Commentary on the Epidemology of Hiprocates.

d. Commentary on Hippocates' De Natura Hominis.

e. Commentary on Galen's Anatomy.

2. His commentaries on early Islamic texts:

a. 'Mujiz al-Qanun: Commentary on Ibn Sina's Qanun fil Tib.

b. Sharh al-Qanun: Commentary on the Canon.

c. Sharh Tashrih al-Qanun: Commentary on the Anatomy of the Canon.

d. Sharh Masa'il Hunain: Commentary on the questions of Hunayn ibn Ishaq.

e. Sharh al-Hidaya fii Tibb: Commentary on Ibn Sina's Guide to Medicine.

f. Sharh Mufradat al-Qanun: Commentary on the simple medicines of Canon.

\footnotetext{
${ }^{15}$ George Makdisi, The Rise of Colleges; Institutions of Learning in Islam and the West (Edinburgh: Edinburgh University Press, 1981), 99-103.

${ }^{16}$ Husain F Nagamia, 24.
}

3. His original contributions to medical texts of his time:

a. Kitab al-Shamili: The Comprehensive book on the art of medicine.

b. Kitab Al-Mukhtarmin al-Aghdiya: The book of Selections Nutrition.

c. Kitab Al-Muhazzab f'il Kuhl: The well arranged book on Opthalmology.

d. Kitab Jame' Al-Daka'ik fil tibb: The Compositive of Exactitudes in Medicine.

e. Kitab al-Shafii: Book of The Healer.

f. Kitab Mawalid Al-Thalash: Book of the Triple Born.

g. Risalahfi Awia' al-Atfaal: Dissertaion on diseases of children.

4. His writings on non-medical subjects:

a. Al-Risala al-Kamiliya fi'l Sira alNabawiyya.

b. Al-Isharat and al-Hidayah: Commentaries on two works of Ibn Sina.

c. Al-Wuraiqat (the little papers): A Summary of Aristotle's Organon and Rhetoric.

d. Tareeq al-Fasaha (Road to eloquence) explanation of 'Al Fusus' (The segments) by Said Hassan bin AlRabbi al-Baghdadi.

e. Al-Mukhtasar fil Ilm Ushulil Hadith (A short account of Methodology of Hadith).

f. An Axplanation of 'Al Tanbih' (Exhortation) by al-Shirazi.

\section{Al-Risala Al-Kamiliya fi'l Sira al- Nabawiyya (Epistle on the Perfect Man)}

The intention of Ibn al-Nafis in this treatise is to relate what Fadil bin Natiq transmitted from the man called Kamil concerning the life story of the Prophet of Islam. ${ }^{17}$ Ibn al-Nafis told the tenet of Islam; the ethics, the prophecies, decay of this world and physical resurrection.

\footnotetext{
${ }^{17} \mathrm{M}$. Meyerhof and J. Schacht, The Theologus of Autodidactus of Ibn al-Nafis (Oxford:Oxford University press, 1968), 38.
} 
In this treatise, Joseph Schacth and Max Meyerhof believed that it is more similiar to the hayy ibn yaqzan written by Ibn Tufayl. They said:

It was a counterpart not to Ibn Sina's Hayy Ibn Yakzan but to the philosopical novel, bearing the same title, of the HispanoMoorish philosopher Muhammad ibn 'Abd al-Malik, known as Ibn Tufayl (d. 581/ 1185). If Ibn Tufayl's aim is to show the discovery of philosophical and mystical truths by an individual created by spontaneous generation on a desert island, or exposed there immediately after his birth, that of Ibn al-Nafis is to describe the same discovery with regard to the main tenets of Islamic religion, the life story of the last Prophet, and the subsequent fate of his community. ${ }^{18}$

Therefore, Joseph Schacht and Max Meyerhof wrote a title on Ibn Nafis' treatise Theologus Autodidactus. It is similiar to that of Edward Pocock who gave the title on Ibn Tufayl's treatise Philosophus Autodidactus. This book was printed in 1671 with Latin translation. However, according to W. Montgomery Watt, the risala kamiliya fi'l sira al-Nabawiyya is disapponting. He compares with the work of Ibn Tufayl which has been called Philosophus Autodidactus but the work of Ibn al-Nafis is greatly inferior. ${ }^{19}$ The general similiarities between the two books proved that Ibn al-Nafis knew the work of Ibn Tufayl. Therefore, he composed his work with Ibn Tufayl work in view. ${ }^{20}$

There are four parts of this risala. Ibn alNafis said:

I have arranged it in four parts: the first part (Fann) explaining how this man called Kamil came to be formed and how he came to know the (natural) sciences and the missions of the prophets; the second on how he came to know the life story of the Prophet; the third on how he came to know the ordinances of religious law; the fourth on how he came to know the happenings which will take place after the

\footnotetext{
${ }^{18}$ Ibid., 2.

${ }^{19} \mathrm{~W}$. Montgomery Watt, "Short Notices of the Theologus Autodidactus of Ibn al-Nafis", in Bulletin of The School of Oriental and African Studies 32, no. 3. (1969), 666.

${ }^{20} \mathrm{M}$. Meyerhof and J. Schacht, 30.
}

death of the Last of the Prophets-may the Blessing of Allah be on him and on them all. ${ }^{21}$

This last part was the most interesting because Ibn al-Nafis uses his method to produce an interpretation of recent history. The editors describe that the sultan to whom Ibn al-Nafis refers in the Fourth Part was likely Sultan Baybars (658/1260-676/1277). It is confirmed by the fact that the Cairo Manuscript is dated 673/1274, thus before the death of sultan Baybars. ${ }^{22}$

\section{The Text Edition}

This text edition is based on Ibn Al-Nafis work's al-Risala al-Kamiliyy a fil-Sira al-Nabawiyya and also of the text of some biographical notice. This text edition is the collaboration of Max Meyerhof and Joseph Schacht. After Max Meyerhof died in 1945, Joseph Schacht continued finishing the text edition. ${ }^{23}$

Joseph Schacht and Max Meyerhof give an adequate introduction. They tell about Ibn al-Nafis completely. They gave the political and scientific background of the author's period, followed by his biography according to the available sources, as well as some remarks on his literary output. ${ }^{24}$

In explaining the biographies of Ibn alNafis, they came across no fewer than eighteen biographical notices of Ibn al-Nafis. However, the editors used the two most detailed biographies of Ibn al-Nafis. According to the editors, both biographies are the oldest among others. The first is the work of Khalil ibn Aybak al-Safadi, al-Wafi bil Wafayat, as the basis of constructing his biography in their edition. This manuscript is preserved in the library of the British Museum (MS. British Museum, Or. 6587, 20v-21v). The second is work of Ibn Fadl Allah al-'Umari (d. 749/1349), Masalikal-Absarfi Mamalikal-Amsar , as supplement of the former manuscript. ${ }^{25}$ And

\footnotetext{
${ }^{21}$ Ibid., 38.

${ }^{22}$ Ibid., 33-34.

${ }^{23}$ Ibid., vii.

${ }^{24}$ Ibid., 2-10.

${ }^{25}$ Ibid., 10-12.
} 
these two biographical notices were printed as an introductory matters in Arabic part of this text edition.

Less than half of of this fifty three pages was translated into English. The rest was summarized by the editors. According to Muhsin Mahdi, ${ }^{26}$ the editors believed that Ibn al-Nafis meant to provide the reader with historical, juridical and theological information. Therefore, it is not important to translate the complete text as it stands because the reader will learn more from their notes what the text reflects. In some cases, if the literary character and overall intention of the narrative appears to have eluded their grasp, it is because the narrative belongs to products of philosophical imagination rather than medical, juridical, or theological learning.

The manuscript edited by Joseph Schacht and Max Meyerhof is the first text edition which is published in 1968. Other scholars have not edited it so that there is no other text edition of this manuscript found.

\section{The Manuscript}

According to Joseph Schacht and Max Meyerhof, this edition is based on two manuscripts, one in Cairo and one in Istanbul. ${ }^{27}$ The Cairo copy exists in the manuscript 209 majami' of the Egyptian library dated 673/1274. This manuscript is older than manuscript in Istanbul. Although not an autograph, this manuscript was written during the life time of Ibn al-Nafis, perhaps by one of his disciples. Unfortunately, this manuscript contains only three of the four parts of the work. ${ }^{28}$

The Istanbul copy is manuscript 461 of the Mustafa Efendi collection, formerly in the library of Ashir Efendi, now preserved in the Suleymaniye Library. This manuscript is younger than the preceding one. Although there are some

\footnotetext{
${ }^{26}$ Muhsin Mahdi, "Book Review of The Theologus Autodidactus of Ibn al-Nafis", in Journal of American Oriental Society 94, no. 2 (1974), 233

${ }^{27}$ I find both of manuscripts in $G A L$, i. $649, \S 37$, no. 10 and Suppl. i. 900, §37, no. 10 and 14.

${ }^{28}$ Joseph Schacht and Max Meyerhof, 36.
}

copyists' errors, this manuscript contains all four parts. ${ }^{29}$

The editors do not mention explicitly a main basis text between these two manuscripts. I assume that they use Istanbul manuscript as the main basis of the text for the fourth part. It is because the Cairo Manuscript contains only the first three parts of the book. For the first three parts, however, they use both of these two manuscripts. ${ }^{30}$

\section{Collation and Editorial Principles}

A. Vrolijk says that variants are differencies in spelling between the two authographs. ${ }^{31}$ In this text edition, the editors treat some variant readings by some footnotes in each pages. The editors find that most of irrelevant variant readings are in the Istanbul manuscript. Some following examples can be interesting points.

5.11. Omit ya after al-ukhra.

9.7. Read faaraqa for qaaraba.

13.3. Add $f a$ before laa.

16. 10. Add ha after li madinat.

According to the editors, the reading of the Cairo Manuscript is prefereble to the Istanbul Manuscript. ${ }^{32}$ In this case, the variant text has been put in the footnote, within the signs, which indicate the manuscripts from which it is taken in order that the reader may be free to form his judgement. They use a letter 'ain for the Istanbul manuscript and a letter mim for the Cairo manuscript, so that the reader may form an idea of the different manuscripts.

For the reader who can understand Arabic text, it is satisfying to read Arabic texts rather than English texts. It is because the editors use Arabic in treating these variant readings. If the

\footnotetext{
${ }^{29}$ Ibid., 37.

${ }^{30}$ See, Ibid., 37.

${ }^{31}$ A.Vrolijk, Bringing a Laugh to a scowling Face (Leiden: t.p., 1998), 113.

${ }^{32}$ See, footnote in Joseph Schacht and Max Meyerhof, 37.
} 
reader prefer reading translation text to Arabic text, the reader can also compare the translation text to the Arabic text easily. It is because the editors provide the numbers in the translation's margin. These numbers refer to the pages of the Arabic text.

According to Witkam and Vrolijk editorial principles, ${ }^{33}$ it is likely that the editors use an ecletic method for their basis of the edition because the editors do not use one basis text from these two manuscripts. They use both of these two manuscripts as the main basis text for the first three parts. However, in the last part of the edition, they use the Istanbul manuscript as the main basis text since the Cairo manuscript did not contain the last part of the text.

Although they provide a very complete introduction, there are thirty seven pages for the introduction, it is unfortunate that this edition do not give any index. Although there is no bibliography in this text edition, the editors provide comprehensive footnotes in their writing. As a result, the reader can trace the source from their footnotes rather than bibliography. The references used in this text edition are varies. There are Arabic, English, German and French. On page four, for instance, they refer to $\mathrm{R}$. Brunschvig's work, La Berberie orientale sous les Hafsides, published in Paris, 1940. The most important thing to note here is that the references used by the editors were published before the publication of this text edition. One of the newest reference they used is F. Rosenthal's article in Bulletin of the History of Medicine published in 1966. Unfortunately, they did not give the title of this article.

Almost on every page of this edition, there are some footnotes. These footnotes support the fact that the editors have a great competency in understanding the classical Arabic text. It is likely that the editors do not emphasize the quantity of footnotes but the quality of footnotes.

\footnotetext{
${ }^{33}$ See, A. Vrolijk, 112. Also, see Witkam, Establishing Stemma: fact or Fiction? (Leiden: t.p., 1988), 96.
}

The editors provide a list of abbreviations in the beginning of the text edition. There are twenty abbrevations on this list. These abbrevations are related to the source They used in this text edition. They, for instance, enlist GAL, EI, JAOS, etc.

They also give excursus at the end of translation text. The excursus are written in alphabetical order from A to $\mathrm{H}$. These excursus are similiar to footnotes but these excursus are more elaborative than footnotes. In this case, the editors not only want to present a complete background of Ibn al-Nafis' biography, but also give an insight of Islamic history, Islamic jurisprudence, and others.

It is unfortunate that in the fourth part, there are some blank sentences. There are five blank sentences in this part. In this case, the editors stated in the introduction of this text edition. They said "...we not only had to rely, for the illegible passages, on a modern copy, but in general had to content ourselves with one late and faulty manuscript; we have therefore been unable to settle the text definitely in a few places..." ${ }^{34}$

\section{Conclusion}

In this text edition, Joseph Schact and M. Meyerhof provide an excellent text edition. They provide adequate information about the life story of Ibn al-Nafis, his political and scientific background, Ibn al-Nafis' works, the manuscript and the text edition itself. This text edition, however, still has some weaknesess, there is no index and no bibliography.

Apart from this weakness, I think that this text edition is an academic text edition. They established a critical text edition based on two incomplete manuscripts. This is not an easy task since it needs patience and a high scholarly standard. Also, they have to select eighteen biographical notices to arrange complete biography of Ibn al-Nafis.

\footnotetext{
${ }^{34}$ Max Meyerhof and Joseph Schacht, 37.
} 


\section{Bibliography}

Brockelmann, C, Geschichte der arabischen Litteratur (GAL i. $649, \S 37$, no. 10 and Suppl. i. 900, § 37, no. 10 and 14).

Makdisi, George. The Rise of Colleges; Institutions of Learning in Islam and the West. Edinburgh: Edinburgh University Press, 1981.

Mahdi, Muhsin. "Book Review of The Theologus Autodidactus of Ibn al-Nafis". In Journal of American Oriental Society 94, no. 2 (1974).

Meyerhof, Max and Schacht, Joseph. The Theologus Autodidactus of Ibn al-Nafis. Oxford: Oxford Unversity Press, 1968.
Meyerhof, Max and Schacht, Joseph. "Ibn alNafis". In Encyclopaedia of Islam III.

Nagamia, Husain F. "Ibn al-Nafis: A Biographical Sketch of the Discover of Pulmonary and Coronary Circulation". In Journal of International Society of Islamic Medicine 1, no. 3 (2003).

Vrolijk, A. Bringing a Laugh to a scowling Face. Leiden: t.p., 1998.

Watt, W. Montgomery. "Short Notices of the Theologus Autodidactus of Ibn al-Nafis", In Bulletin of The School of Oriental and African Studies 32, no. 3. (1969).

Witkam, J.J. Establishing Stemma: fact or Fiction? Leiden: t.p., 1988. 